\title{
Effect of Nursing Intervention on Knowledge of Malaria Prevention among Mothers of Under-Five Children in Selected Primary Health Care, Mushin Local Government, Lagos
}

\author{
Article by Olubiyi, S.K. ${ }^{1}$, Folami F. ${ }^{2}$, Adebanjo A.T ${ }^{3}$ \\ ${ }^{1}$ Department of Nursing Science, University of Ilorin \\ ${ }^{2,3}$ Department of Nursing, College of Medicine, University of Lagos \\ E-mail: Flofolami@yahoo.com ${ }^{2}$
}

\begin{abstract}
Introduction: Malaria is a major public health problem in Africa. The disease is a significant contributor to the poor health situation in Africa, in which Africa alone is estimated to lose at least US\$ 12 billion per year in direct losses e.g. illness, treatment, premature death. Almost 1 out of 5 deaths of children under 5 in Africa is due to malaria. Due to the high figure, there is still the need for continued awareness and renewed commitment for the prevention of malaria especially among the risk group (under-five and pregnant women).

Objective: The study assessed the effect of the nursing intervention on knowledge of malaria prevention among mothers of under five in a selected PHC and also described the level of knowledge of mothers on malaria in a selected PHC in Mushin LGA pre and post-intervention.

Methods: This is a quasi-experimental design. Data collection was done using a structured, selfadministered questionnaire to obtain information from the participants. This study was carried out in three phase which involved three phase (pre-intervention, intervention and post-intervention) activities in process of data collection.

Results: The findings of the study showed significant difference between posttest knowledge of malaria prevention and pretest knowledge of malaria prevention among mothers of under-five children.

Conclusion: This study revealed that knowledge of mothers of under-five on malaria and various malaria prevention strategies improved. This study recommended that Mothers of under-five should be regularly exposed to training programs on malaria and malaria prevention.
\end{abstract}

Keywords: Nursing intervention, Malaria prevention, Under-five children, Prevalence.

\section{Introduction}

Malaria is a major public health problem in Africa The disease is a significant contributor to the poor health situation in Africa, in which Africa alone is estimated to lose at least US\$ 12 billion per year in direct losses e.g. illness, treatment, premature death. It is the 2nd leading cause of death from infectious diseases in Africa, after HIV/AIDS. Almost 1 out of 5 deaths of children under 5 in Africa are due to malaria (Nigeria Malaria Factsheet, 2011). Malaria is the most prevalent parasitic endemic disease in Africa, South East Asia region, Eastern Mediterranean region (WHO, 2011). It is a preventable disease yet it remains one of the major health problems in Nigeria (Olorunfemi, 2013). Globally, it has been estimated that 3.2 billion people in 97 countries are at risk of being infected with malaria, and 1.2 billion are at high risk (>1 in 1000 chance of getting malaria in a year) (WHO global malaria program, 2014). Accordingly, WHO estimates 214 million new cases of malaria worldwide (range 149-303 million) and the disease led to 438000 deaths, of which 88\% occur in Africa in 2015. Malaria lays a heavy economic and social burden on families, communities and societies, draining World economies of an estimated US\$2.7 billion dollars a year (Global Funding, 2011).

Among the sub-Saharan Africa countries, Nigeria has its own fair share of the Malaria burden, where it accounts for more cases and deaths than any other country in the world as $97 \%$ of its population is at risk with its remaining 3\% living in malaria free highlands (Nigeria Malaria Factsheet, 2011). The highest burden is seen in the southern parts of the country due to a longer rainy season that favors the breeding of mosquitoes National Malaria Control Programme (2008). 
According to Olalekan, \& Nurudeen, 2013 reported that a child is sick of malaria between 2 and 4 times in a year and it was estimated that malaria was responsible for nearly 110 million clinical cases and estimated 300,000 deaths per year, including up to $11 \%$ of maternal mortality. This compares with 215,000 deaths per year in Nigeria from HIV/AIDS. (Okonkwo, 2013).

In Nigeria, the amount spent on malaria is about 611.7 Naira (USD 5.1) per head per month and 7,340 Naira (USD 61.2) per year. For a country with a population of about 120 million this translates to about 880,801 million Naira per annum representing about $12.0 \%$ of the Gross Domestic Product (Jimoh, 2007). Malaria control activities in Nigeria are planned and implemented through the primary health care (PHC). In Nigeria, PHC as primary level of health care mainly focus on the prevention of malaria as a disease rather than treatment or cure of malaria cases.

\section{Statement of problem}

Despite numerous interventions that have been instituted so far malaria situation in Nigeria is deteriorating (Fatungase, k., Amoran, O., Alausa, K., 2012). According to the Nigerian national malaria strategic plan 2014-2020, malaria is responsible for $60 \%$ of outpatient visits to health facilities, $30 \%$ of childhood deaths, $25 \%$ of deaths in children under one year, and $11 \%$ of maternal deaths. Hence, the researcher's needs to assess the effect of nursing intervention on the knowledge of malaria prevention among mother of under five children in a selected PHC in Mushin LGA.

\section{Objective}

(1) To assess the effect of nursing intervention on knowledge of malaria prevention among mothers of under five in a selected PHC in mushin LGA

(2) To determine the level of knowledge on malaria prevention among mothers of under five children in a selected PHC in Mushin LGA

(3) To evaluate the effect of nuring intervention on knowledge of malaria prevention among mothers of under five in a selected PHCs in Mushin LGA post intervention

\section{Research questions}

- What is the level of knowledge of malaria among mothers on malaria in selected a PHC in mushin pre intervention?

- What is the level of knowledge of malaria prevention among mothers of under five in a selected phc in mushin LGA?

- What is the effect of nursing intervention on knowledge of malaria prevention among mothers of underfive in a selected phc in mushin LGA post intervention?

\section{Hypothesis}

There is no significant difference between knowledge of malaria and prevention of malaria among mothers of under five.

\section{Methodology}

The study design for this is a quasi-experimental study design. The study was conducted among mothers of under five children in selected primary health care centre in Mushin local government. The target populations are all mothers of under five children Data collection was done using a structured, self-administered questionnaire to obtain information from the participants. This study involved three phase (pre-intervention, intervention and post intervention) activities in process of data collection. Three trained research assistants assisted in the data collection, prior to the intervention. Four weeks after the intervention, quantitative data was collected with the same instrument from the respondents. The data was analysed by the use of descriptive/analytical methods. The data was reviewed, organized and entered into a computer running the statistical package of social science (SPSS version) 22. Frequency tables were made and numerical data expressed in frequency distribution tables. The result was tested using descriptive and inferential statistical analysis of dependent t-test at 0.05 level of significance to answer the research questions and test the hypotheses. 


\section{Data analysis and result presentation}

Table 1. Frequency and percentage showing demographic data of participants in selected primary health centre

\begin{tabular}{|l|l|l|}
\hline Variables & $\begin{array}{c}\text { Frequency } \\
\mathrm{n}=40\end{array}$ & Percentage \% \\
\hline Age & & \\
\hline Below 20years & 6 & 15.0 \\
\hline 20-29years & 20 & 50.0 \\
\hline 30-39years & 9 & 22.5 \\
\hline 40-49years & 5 & 12.5 \\
\hline Marital status & & \\
\hline Single & 3 & 7.5 \\
\hline Married & 35 & 87.5 \\
\hline Divorced & 1 & 2.5 \\
\hline Widowed & 1 & 2.5 \\
\hline Levelofeducation & & \\
\hline Primary & 6 & 15 \\
\hline Secondary & 20 & 50 \\
\hline College & 5 & 12.5 \\
\hline Others & 9 & 22.5 \\
\hline
\end{tabular}

Table 1 showed that 6 participants (15\%) were below 20years, 20 participants (50\%) were between 20-29 years, 9 participants $(22.5 \%)$ were between 30-39years and $5(12.5 \%)$ participants were between 40-49years. Table 1.1 above showed 3 participants $(7.5 \%)$ were single, 35 participants $(87.5 \%)$ were married, $1(2.5 \%)$ participant was divorced, and 1(2.5\%) participant was widowed. table1.1 above showed that $6(15 \%)$ participants had primary education, 20 participants $(50 \%)$ had secondary education, while 5 participants $(12.5 \%)$ had college education and 9 participants $(22.5 \%)$ had other skills.

Table 2. Frequency and percentage showing demographic data of participants in selected primary health centre

\begin{tabular}{|l|l|l|}
\hline Employment status & Frequency & Percentage (\%) \\
\hline Public service & 8 & $20.0 \%$ \\
\hline Self employed & 14 & $35.0 \%$ \\
\hline Private sector & 8 & $20.0 \%$ \\
\hline Others & 10 & $25.0 \%$ \\
\hline No. of children & Frequency & Percentage (\%) \\
\hline 1 & 20 & $50 \%$ \\
\hline 2 & 14 & $35 \%$ \\
\hline 3 & 6 & $15 \%$ \\
\hline 4 & 0 & $0 \%$ \\
\hline $\begin{array}{l}\text { No. of children aged 0 } \\
\text { to 5 }\end{array}$ & Frequency & Percentage (\%) \\
\hline 1 & 36 & $90 \%$ \\
\hline 2 & 4 & $10 \%$ \\
\hline 3 & 0 & $0 \%$ \\
\hline 4 & 0 & $0 \%$ \\
\hline $\begin{array}{l}\text { Age of children aged } \\
\text { 0to5 }\end{array}$ & Frequency & Percentage (\%) \\
\hline $0-18$ months & 10 & 25 \\
\hline $2-3$ years & 20 & $50 \%$ \\
\hline $4-5$ years & 10 & $25 \%$ \\
\hline
\end{tabular}


DOI: $10.21522 /$ TIJPH.2013.06.01.Art008

ISSN: $2520-3134$

Table 2 also shows that 8 participants (20\%) were civil servant, 14 participants (35\%) were selfemployed, 8 participants (20\%) works with private sector and 10 participants $(25 \%)$ were others.

Table 3. Relationship between the demographic variables and knowledge on malaria (pre-test) $\mathrm{N}=40$

\begin{tabular}{|c|c|c|c|c|}
\hline $\begin{array}{l}\text { Demographic } \\
\text { Variables }\end{array}$ & $\begin{array}{l}\text { Frequency of } \\
\text { mothers with } \\
\text { good knowledge }\end{array}$ & $\begin{array}{l}\text { Frequency of } \\
\text { mothers with } \\
\text { average } \\
\text { knowledge }\end{array}$ & $\begin{array}{l}\text { Frequency of } \\
\text { mothers with poor } \\
\text { knowledge }\end{array}$ & $\mathrm{P}$ - value \\
\hline $\begin{array}{l}\text { Age } \\
\text { Below } 20 \text { years } \\
\text { 20-29 years } \\
30-39 \text { years } \\
40-49 \text { years }\end{array}$ & $\begin{array}{l}1 \\
1 \\
2 \\
0 \\
\end{array}$ & $\begin{array}{l}2 \\
9 \\
3 \\
4 \\
\end{array}$ & $\begin{array}{l}3 \\
10 \\
4 \\
1 \\
\end{array}$ & 0.608 \\
\hline $\begin{array}{l}\text { Level of } \\
\text { Education } \\
\text { Primary } \\
\text { S.S.C.E } \\
\text { college } \\
\text { Others }\end{array}$ & $\begin{array}{l}2 \\
0 \\
2 \\
0\end{array}$ & $\begin{array}{l}3 \\
9 \\
2 \\
4\end{array}$ & $\begin{array}{l}1 \\
11 \\
1 \\
5\end{array}$ & 0.336 \\
\hline $\begin{array}{l}\text { Marital status } \\
\text { Single } \\
\text { Married } \\
\text { Divorced } \\
\text { Widowed }\end{array}$ & $\begin{array}{l}0 \\
4 \\
0 \\
0\end{array}$ & $\begin{array}{l}1 \\
15 \\
1 \\
1 \\
\end{array}$ & $\begin{array}{l}2 \\
16 \\
0 \\
0 \\
\end{array}$ & 0.465 \\
\hline $\begin{array}{l}\text { Employment } \\
\text { status } \\
\text { Public service } \\
\text { Self employed } \\
\text { Private sector } \\
\text { Others }\end{array}$ & $\begin{array}{l}1 \\
2 \\
0 \\
1\end{array}$ & $\begin{array}{l}3 \\
8 \\
5 \\
2\end{array}$ & $\begin{array}{l}4 \\
4 \\
3 \\
7\end{array}$ & 0.407 \\
\hline Total & 4 & 18 & 18 & \\
\hline
\end{tabular}

The table above illustrates the statistical analysis between the socio-demographic variables, their level of knowledge of malaria, and the statistical relationship between the socio-demographic variables and knowledge of malaria. It was deduced from the table that the overall knowledge of the research respondents in the pre-test was assessed and majority of the respondents had inadequate knowledge of malaria prior to nursing intervention (18), while only a few possessed adequate knowledge of malaria (4).

Table 4. Relationship between the demographic variables and knowledge of malaria prevention $\mathrm{N}=40$

\begin{tabular}{|l|l|l|l|l|}
\hline $\begin{array}{l}\text { Demographic } \\
\text { Variables }\end{array}$ & $\begin{array}{l}\text { Frequency of } \\
\text { mothers with } \\
\text { Good knowledge }\end{array}$ & $\begin{array}{l}\text { Frequency of } \\
\text { mothers with } \\
\text { average } \\
\text { knowledge }\end{array}$ & $\begin{array}{l}\text { Frequency of } \\
\text { mothers with } \\
\text { Poor } \\
\text { knowledge }\end{array}$ & $\mathbf{P}$ - value \\
\hline Age & & 0 & 4 & 0.362 \\
Below 20 years & 2 & 7 & 8 & \\
20-29 years & 5 & 3 & 5 & \\
30-39 years & 1 & 0 & 3 & 0.437 \\
40-49 years & 2 & 2 & 2 & \\
\hline $\begin{array}{l}\text { Level of } \\
\text { Education }\end{array}$ & 2 & 6 & 10 & \\
Primary & 4 & 6 & & \\
\hline
\end{tabular}




\begin{tabular}{|l|l|l|l|l|}
\hline S.S.C.E & 1 & 1 & 3 & \\
College & 3 & 1 & 5 & \\
BSc & & & & \\
\hline Marital status & & 1 & 2 & 0.708 \\
Single & 0 & 9 & 16 & \\
Married & 10 & 0 & 1 & \\
Divorced & 0 & 0 & 1 & 0.573 \\
Widowed & 0 & & & \\
\hline Employment & & 2 & 5 & \\
status & 1 & 0 & 9 & \\
Public service & 5 & 3 & 3 & \\
Self employed & 2 & 5 & 3 & \\
Private sector & 2 & & $\mathbf{2 0}$ & \\
Others & $\mathbf{1 0}$ & $\mathbf{1 0}$ & \\
\hline Total &
\end{tabular}

The table above illustrates the statistical analysis between the socio-demographic variables, their level of knowledge of malaria prevention, and the statistical relationship between the sociodemographic variables and knowledge of malaria prevention. It was deduced from the table that the overall knowledge of the research respondents in the pre-test was assessed and majority of the respondents had inadequate knowledge of malaria prevention prior to Nursing- intervention (20) while only a few possessed adequate knowledge of malaria (10).

Table 5. Table showing the relationship between the demographic variables and knowledge on malaria (posttest) $\mathrm{N}=40$

\begin{tabular}{|c|c|c|c|c|}
\hline $\begin{array}{l}\text { Demographic } \\
\text { Variables }\end{array}$ & $\begin{array}{l}\text { Frequency of } \\
\text { mothers with } \\
\text { Good knowledge }\end{array}$ & $\begin{array}{l}\text { Frequency of } \\
\text { mothers with } \\
\text { average } \\
\text { knowledge } \\
\end{array}$ & $\begin{array}{l}\text { Frequency of } \\
\text { mothers with } \\
\text { Poor } \\
\text { knowledge } \\
\end{array}$ & $P$ - value \\
\hline $\begin{array}{l}\text { Age } \\
\text { Below } 20 \text { years } \\
20-29 \text { years } \\
\text { 30-39 years } \\
40-49 \text { years }\end{array}$ & $\begin{array}{l}4 \\
19 \\
8 \\
5 \\
\end{array}$ & $\begin{array}{l}2 \\
1 \\
1 \\
0\end{array}$ & $\begin{array}{l}0 \\
0 \\
0 \\
0\end{array}$ & 0.073 \\
\hline $\begin{array}{l}\text { Level of } \\
\text { Education } \\
\text { Primary } \\
\text { S.S.C.E } \\
\text { College } \\
\text { Others } \\
\end{array}$ & $\begin{array}{l}6 \\
18 \\
3 \\
9\end{array}$ & $\begin{array}{l}0 \\
2 \\
2 \\
0\end{array}$ & $\begin{array}{l}0 \\
0 \\
0 \\
0\end{array}$ & 0.676 \\
\hline $\begin{array}{l}\text { Marital status } \\
\text { Single } \\
\text { Married } \\
\text { Divorced } \\
\text { Widowed }\end{array}$ & $\begin{array}{l}3 \\
31 \\
1 \\
1\end{array}$ & $\begin{array}{l}0 \\
4 \\
0 \\
0\end{array}$ & $\begin{array}{l}0 \\
0 \\
0 \\
0\end{array}$ & 0.774 \\
\hline $\begin{array}{l}\text { Employment } \\
\text { status } \\
\text { Public service } \\
\text { Self employed } \\
\text { Private sector } \\
\text { Others }\end{array}$ & $\begin{array}{l}7 \\
12 \\
8 \\
9\end{array}$ & $\begin{array}{l}1 \\
2 \\
0 \\
1\end{array}$ & $\begin{array}{l}0 \\
0 \\
0 \\
0\end{array}$ & 0.278 \\
\hline Total & 36 & 4 & $\mathbf{0}$ & \\
\hline
\end{tabular}


DOI: 10.21522/TIJPH.2013.06.01.Art008

ISSN: $2520-3134$

The table above illustrates the statistical analysis between the socio-demographic variables, their level of knowledge of malaria, and the statistical relationship between the socio-demographic variables and knowledge of malaria. It was deduced from the table that the overall knowledge of the research respondents in the pre-test was assessed and majority of the respondents had good knowledge of malaria after Nursing intervention (36) while only a few possessed average knowledge of malaria (4).

Table illustrating the overall level of knowledge of malaria prevention of the mothers (post-test) $\mathrm{N}=40$

\begin{tabular}{|l|l|l|}
\hline & Frequency & Percent \\
\hline Good & 35 & 87.5 \\
Average & 5 & 12.5 \\
Total & 40 & 100.0 \\
\hline
\end{tabular}

The table above illustrates the level of knowledge of malaria prevention post-nursing intervention which was $87.5 \%$.

Table showing the paired sample t-test analysis between the pre and post-test on knowledge of the mothers of under-five's on malaria and malaria prevention

$\mathrm{N}=40$

\section{Paired samples test}

\begin{tabular}{|l|l|l|l|}
\hline & Df & P-value \\
\hline $\begin{array}{l}\text { Pre-test Overall knowledge on malaria - Pre-test } \\
\text { Overall knowledge on malaria prevention }\end{array}$ & 539 & 39 & 0.593 \\
$\begin{array}{l}\text { Pre-test Overall knowledge on malaria - Post-test } \\
\text { Overall knowledge on malaria }\end{array}$ & 9.777 & 39 & $* 0.000$ \\
$\begin{array}{l}\text { Pre-test Overall knowledge on malaria - Post-test } \\
\text { Overall knowledge on malaria prevention }\end{array}$ & 9.316 & 39 & $* 0.000$ \\
$\begin{array}{l}\text { Pre-test Overall knowledge on malaria prevention } \\
\text { Post-test Overall knowledge on malaria }\end{array}$ & 8.420 & 39 & $* 0.000$ \\
$\begin{array}{l}\text { Pre-test Overall knowledge on malaria prevention } \\
\text { Post-test Overall knowledge on malaria prevention }\end{array}$ & 8.342 & 39 & $* 0.000$ \\
$\begin{array}{l}\text { Post-test Overall knowledge on malaria - Post-test } \\
\text { Overall knowledge on malaria prevention }\end{array}$ & -.374 & 39 & 0.711 \\
\hline
\end{tabular}

Note: p-value $<0.05$ is statistically significant $\left(^{*}\right)$

The statistical table above illustrates the test statistic (t-test), degrees of freedom (df) and the respective $\mathrm{p}$-values derived for the analyzed variables. It was found out that there was a statistically significant association between the knowledge on malaria in pre-test vs knowledge on malaria in posttest (p-value $<0.05$ ), knowledge on malaria in pre-test vs knowledge on malaria prevention in post-test (p-value $<0.05$ ), knowledge on malaria prevention in pre-test vs knowledge on malaria in post-test (pvalue $<0.05)$, knowledge on malaria prevention in pre-test vs knowledge on malaria prevention in post-test ( $\mathrm{p}$-value $<0.05$ ). this result denotes that the nursing intervention after the pre-test on the level of knowledge yielded a better level of knowledge and that knowledge is dependent on Nursing 
intervention as shown in the statistically significant difference between their performances in pre and post-test.

\section{Discussion of findings}

\section{Socio-demographic variables and knowledge}

The relationship between the demographic variables were assessed with the mother's level of knowledge on malaria and its prevention pre and post-nursing intervention, and it was found out that the age bracket 20-29 had the highest frequency of participants with poor knowledge of malaria and malaria prevention prior to nursing intervention and also possessed the highest number of good knowledge of malaria and malaria prevention post-nursing intervention with p-values $>0.05$ pre and post-nursing intervention respectively which was not statistically significant, Secondary School leaving certificate holders had the highest number of participant possessing poor knowledge of malaria and malaria prevention prior to nursing intervention and also possessed the highest number of good knowledge of malaria and malaria prevention post-nursing intervention with p-values $>0.05$ respectively, while the married participants had the highest number of poorly knowledgeable mothers on malaria and malaria prevention prior to nursing intervention and also possessed the highest number of good knowledge of malaria and malaria prevention post-nursing intervention ( $\mathrm{p}$-values $>0.05$ ), people who did not specify their employment status were the most un-knowledgeable on malaria and its prevention prior to nursing intervention and also possessed the highest number of good knowledge of malaria and malaria prevention post-nursing intervention with $\mathrm{p}$-values $>0.05$ respectively. This may be due to the fact that majority of these mothers are not scientifically oriented and need proper awareness and training on malaria its prevention by trained professionals (Nurses) so as to help ensure general good health and well-being of their babies and are therefore reduce child morbidity and mortality. There was no statistically significant association between the demographic variables and the knowledge of malaria and malaria prevention pre and post-nursing intervention, which implies that the level of knowledge of the mothers is not affected by their age, level of education, marital status and their employment status but on the information they get from qualified personnel on malaria and malaria prevention.

\section{Knowledge on malaria}

The overall knowledge on malaria was computed and it was derived that pre-nursing intervention, majority of the mothers possessed inadequate knowledge of malaria with eighteen (18) mothers possessing poor knowledge and average knowledge respectively while only four mothers possessed good knowledge prior nursing intervention. But upon nursing intervention, the level of knowledge of the mothers took a turn and proceeded to yield a positive effect of nursing intervention as thirty-six (36) out of forty mothers had good knowledge of malaria and only four possessing average knowledge.

\section{Knowledge of malaria prevention}

The overall knowledge on malaria prevention was computed and it was derived that pre-nursing intervention, majority of the mothers possessed inadequate knowledge of malaria prevention with ten (10) mothers possessing poor knowledge of malaria prevention and average knowledge of malaria prevention respectively while only four mothers possessed good knowledge prior nursing intervention. But upon nursing intervention, the level of knowledge of the mothers on malaria prevention yielded a good effect of intervention as thirty-five (35) i.e $87.5 \%$ of the mothers out of forty mothers had good knowledge of malaria prevention and only five possessing average knowledge of malaria prevention.

\section{Discussion of hypotheses}

Ho1: There is no statistically significant relationship between the knowledge of malaria and prevention of malaria among mothers of under-five.

In this study, we evaluated the statistical relationship between the mother's knowledge of malaria and malaria prevention and we were able to make some assertions based on the p-values derived as an 
indication of the statistical relationship between the assessed variables. It was found out that there was a statistically significant association between the knowledge on malaria pre-intervention and the knowledge on malaria in post-nursing intervention ( $p$-value $<0.05$ ), this implies that nursing intervention is of paramount importance in malaria awareness to the mothers of under-five children and to the wider general public so as to equip as many people as possible with adequate knowledge of malaria so as to significantly decrease the ignorance level of mothers and the general public on malaria. The knowledge on malaria pre-intervention and the knowledge on malaria prevention post intervention were also compared using a paired sample t-test and there was a statistically significant difference between the knowledge of the mothers on malaria prior to intervention and knowledge of malaria prevention post-intervention. This implies that the knowledge of malaria prevention is dependent on nursing intervention because it was not until after nursing intervention that a statistically significant difference emerged between knowledge of malaria preintervention and knowledge of malaria prevention post intervention(p-value $<0.05$ ). The knowledge on malaria prevention preintervention and the knowledge on malaria post-intervention was also assessed and we arrived at the conclusion that there was a statistically significant difference between the knowledge of malaria before intervention and the knowledge of malaria after intervention ( $\mathrm{p}$-value $<0.05$ ), which points out the fact that there will not have been a difference in knowledge if nursing intervention did not come into play. Knowledge on malaria prevention pre-intervention and knowledge on malaria prevention post-intervention were assessed and the comparison resulted in a p-value $<0.05$ which denotes a statistically significant difference between them. This result denotes that the nursing intervention after the pre-test on the level of knowledge yielded a better level of knowledge of malaria and its prevention and that knowledge of malaria and malaria prevention is dependent on Nursing intervention as shown in the statistically significant difference between their performances in pre and post-intervention.

\section{Conclusion}

Based on the findings of this study, mothers of under-five in the selected primary health centre did not have adequate knowledge on malaria and malaria prevention. This study achieved a significant difference in post-intervention knowledge on malaria and malaria prevention. Hence, the nursing intervention has significantly improved the knowledge of mothers of under-five children's on malaria and malaria prevention.

\section{Recommendations}

1. Mothers of under-five should be regularly exposed to training programs on malaria and malaria prevention

2. Policies and guidelines on malaria prevention should be regularly reviewed by hospitals

\section{References}

[1]. Achan Quinine. (2011). An old antimalarial drug in a modern world. Malaria Journal, 1475-2875,142144.

[2]. Adedotun, A., Morenikeji, O.,\& Odaibo, O. (september, 2010). Knowledge, attitudes and practices about malaria in an urban community in south-western Nigeria. journal of vector borne diseases, 47:155-159.

[3]. Adegun, A.,Adegboyega, A.,\& Awosusi, A. (2011). Knowledge and the preventive strategies of malaria. Peer journal, 883-889.

[4]. Ajayi,I., Falade, O.,Bamgboye, E.,Oduola, A.,\& Kale, O. (2008). Assesment of treatment guideline to improve home management of malaria in children in rural south-west Nigeria. Malaria journal, 7-24.

[5]. Akande, M.,\& Musa, O. . (2005). Epidemiololgy Of Malaria In Africa. Africa Journal Of Clinical And Experimental Microbiology., 1575-689A:107-111.

[6]. Arogundade,E., Adebayo, S., Anyanti, J.,Nwokolo,E., Ladipo,O., Ankomah,A.,\& Meremikwu, M. (2011). Relationship between caregivers' misconceptions and non use of ITNs by under- five Nigeria children. Malaria journal, 10:170.

[7]. Autino, B., Noris, A., Russo, R., \& Casteli, f. (2012). Epidemiology of malaria in endemic areas. Mediterranean Journal Of Heamatolgy and infectious diseases, 2035-3006. 
[8]. Ayodeji, A., Oluwaseun, A., \& Eniola, C.,. (2015). knowledge of malaria prevention among pregnant women and female caregiversof under-five children in rural southwest Nigeria. Peer Journal.

[9]. Centre for disease control. (2015). medication and dosage for prevention of malria while travelling. http://www.cdc.gov/malarai.

[10]. Centers for disease control. (2011, august 19). Retrieved march 19, 2016, from http://www.cdc.gov/malaria/abouthistory.

[11]. Clive Shiff. (2010). Epidemiology of malaria: integrated approach to malaria control. Clin Microbial, 15(2): 278-293.

[12]. David Sullivan. (2010). Epidemiology and pathology of malaria. johnshopkins bloomberg school of public health.

[13]. Dehli, N.(2014). Guidelines for Diagnosis and treatment of Malaria in India.

[14]. Fatungase, k., Amoran, O., Alausa, K. (2012). The effect of health education intervention on home management of malaria among the caregivers of children aged under 5 years in ogun state, Nigeria.

[15]. Federal Ministry of Health. ( 2011, june). Retrieved march 2016, from Nigeria National policy on Malaria Diagnosis and Treatment: http://www.nmcpnigeria.org

[16]. Francis Cox. (2010). History of the discovery of malaria parasites and their vectors. parasitic vectors, 1756-3305;3-5.

[17]. Global Funding Of Innovation For Neglected Diseases. (2011, december). Retrieved from global funding website.

[18]. Hays, N., Santa,B. (2013). Epidemic and pandemic: their impacts on human history. World malaria journal, ABC-CL10.

[19]. Hay, S.,Smith, D.,Snow, R. (april 2008). Measuring malaria endemicity from intense to interrupted transmission. Elsevier sponsored documents, 8(6): 269-378.

[20]. Health protection Agency. (n.d.). Malaria treatment guidelines. Retrieved april 2016, from http://www.hpa.org.uk/topics/infectious diseases/infectionAZ/Malaria/Guidelines/mal20quidelinesTreatment/

[21]. Jacquerioz. (Rev.Oct 7,2009). Drugs for preventing malaria in travellers. Cochrane database.

[22]. Jimoh. (2007). Quantifying the burden of malaria in Nigeria using the willingness to pay approach. 14787547-5-6-1-8.

[23]. Killeen, G.,\& Nakul,C. (2014). Potential causes and consequences of behavioural resilience and resistance in malaria vector populations. Malaria Journal, 1475-2875:13-97.

[24]. Lalloo, D., \& Hill, D. (June,2008). preventing malaria in travelers. biomedical journal, 336:1362.

[25]. Malaria policy center. (2014, february 17). malaria 101. Retrieved may 06, 2016, from http://www.malariaploicycenter.org/malaria101/history-malaria

[26]. National department of health South Africa. (2009). The guidelines for prevention of malaria in South Africa.

[27]. Nigeria Malaria Factsheet. Economic Section, United State Embassy In Nigeria. . (2011, december on 26 march 2015). Retrieved from Nigeria US Embassy website: http://www.nigeria.usembassy.org

[28]. Nigeria Malaria Indicator Survey 2010. (2012, january accessed on 27 march 2015). Nigeria Malaria Control Programme. Retrieved from dhsprogram website: http://www.dhsprogram.com/pubs/mis8/mis8.pdf

[29]. Okonkwo, R C. (2013). Prevalence of HIV Infection In Pulmonary Tuberculosis Suspects. Advances In Life Science And Technology, 2224-7181:87-90.

[30]. Olalekan, S.,\& Nurudeen, S. (2013). Malaria burden and effectiveness of malaria control measures in Nigeria. Journal of Economics and sustainable development, 2222-1700:295-308.

[31]. olorunfemi., E.A. (2013). Impact of health education intervention on malaria prevention practices among nursing mothers in rural communities in Nigeria. Nigeria Medical journal, 115-122.

[32]. Pelletier \& Caventou. (2012). 'Suite:Des recherches chimiques sur les quinquinas', . Annales de chimie et de physique, vol. 15, pages 337-365.

[33]. Roll Back Malaria. (2008). global strategy plan 2005-2015. Retrieved from rbm.who website: http://www.rbm.who.int/forumv/docs/gspen.pdf.

[34]. Singh. (2016). Ownership and use of insecticide treated nets during pregnancy in sub-sahara Africa. Malaria Journal.

[35]. Sok Chul Hong. (december 2009). The burden of early exposure to malaria in the united states in the 1800s. 67(4):1001-1035. 
DOI: $10.21522 /$ TIJPH.2013.06.01.Art008

ISSN: $2520-3134$

[36]. The Executive summary of the Global Malaria Action Plan For The Roll Back Malaria Partnership 2008. (2008). Retrieved from roll back malaria: http://www.rollbackmalaria.org/micrositos/gmap/0-5.pdf

[37]. Udonwa, N.,Gyuse, A., \& Etokidem, A. (2010). Malaria: Knowledge and prevention practices among school adolescents in a costal community in Calabar, Nigeria. Africa Journal, 2(1): 3-5.

[38]. WHO. (2006, july). Global Malaria programme (Gmap). Retrieved april 2016, from Use of indoor residual sprayng for scaling up global malaria control and elimination: http://www.WHO.int/malaria.

[39]. WHO global malaria program. (2014). world malaria report. Retrieved from roll back malaria : http://www.rollbackmalaria.org/files/files/about/9789241564830-eng.pdf

[40]. WHOguidance forcountries on combining IRS with ITNS. (march 2014). World Health Organisation.

[41]. World health organisation. (2015). WHO Guidelines for treatment of malaria.

[42]. WHO. (2009). international travel and health. malaria journal.

[43]. World Health Organisation Lives At Risk. (2013). malaria in pregnancy. Retrieved from WHO.int: http://www.WHO.int/features/2013/04b/en.

[44]. World Health Organization. (2009). World Malaria Report 2008 Geneva. Retrieved from WHO Web site: WHO/HTM/GMP/

[45]. World health organisation. (n.d.). WHO media centre information on malaria. Retrieved April 24th, 2016, from http://www.WHO.int/mediacentre/factsheets/fs094/en/

[46]. WHO. (2013, september). recommendations for acheiving unuversal coverage with long lasting insectiidal treated nets. Retrieved april 2016, from http://www.who.int/malaria/mpac sp13 vcteg universal llin coverage report pdf. 